\title{
Projects to Reduce the Coastal Erosion of the Romanian Black Sea Area
}

\author{
Mari-Isabella Stan, Kamer-Ainur Aivaz, Ionela Ionițiu
}

\begin{abstract}
The entire Romanian Black Sea coastline is subject to erosion under the conditions of coastal dynamics changing. The problem the Romanian coastal area is facing is the accelerated number of conflicts between coastal development and coastal erosion. The purpose of this article is to present the projects realized and proposed for the protection and rehabilitation of the Romanian coastal area. The implementation of projects from non-reimbursable European funds to reduce erosion in the coastal area of the Romanian Black Sea coast aims to protect and improve the quality of the environment and the standard of living.
\end{abstract}

Keywords - Black Sea, coastal zone, projects, erosion

\section{INTRODUCTION}

Coastal erosion is the process of removing material from the coast due to the imbalance in the supply and export of materials [1] under the action of waves, tidal currents and / or human activities, usually leading to a shoreline withdrawal.

The problem the coastal area is facing is the accelerated number of conflicts between coastal development and coastal erosion; these conflicts are further aggravated by climate change [2].

Understanding the coastal erosion process requires an insight into all the natural and anthropic factors that interact along the shoreline [4].

It was noticed that the land cover and use changes in Romania were crowded around large urban centers or regions, such as the Black Sea seaside - Constanta [3].

Along the Romanian coastline, the withdrawal of the shoreline has taken place at a rapid pace, especially in the last decades. The natural factors that easily move the sand and the unconsolidated soils in the coastal area, leading to rapid changes in the position of the coastline are the wind, waves and currents. Also, the anthropic activities had as a result the bringing in small quantities of sediments into the Romanian coastal system. This significant reduction of sediment resulted in erosion and shoreline withdrawal.

The objective of this paper is to present the projects realized and proposed for the protection and rehabilitation of the Romanian coastal area.

\section{THE SITUATION OF THE ROMANIAN COASTAL ZONE}

Over time, numerous specialized studies and researches have been carried out that have inventoried relevant information regarding the coastal area of Romania.

ISSN 2392-6139 / ISSN-L 1584-5990 


\section{sciendo}

110 Ovidius University Annals Series: Civil Engineering, Year 21, 2019

According to the study developed in activity 1.1 of the first MARSPLAN-BS project, the Romanian southern coast is built on several types of coastal constructions, including extensive hydrotechnical structures to protect the tourist beaches and urban settlements, against the impact induced by human activities, including maritime navigation works / port extensions [8].

The present coastal protection system, effectively redesigned on the new environmental resource base, but built mainly since 1980, has led to fluctuations in the coastal position, because these structures were determined by the formation of localized deposits, not observed in previously.

Along the southern coast, in a period of about 70 years from 1936, closely related to the development of the interior hydrotechnical works and the extension of the navigation constructions, followed by the progressive intensification of the erosion processes, some coastal protection systems have been designed and executed.

The coastal protection works adjust the local alluvial transport and help maintain a beach along the seafront. For the coastal protection there are a large number of technical solutions against the coastal erosion used along the Romanian shoreline: offshore breakwaters, coastal transversal breakwaters, detached breakwaters / jetties, groynes, sea walls, stepped seawall etc. [5].

Although much of southern Romania was protected by coastal constructions, they did not have the expected effect in stabilizing the shoreline. Even the implementation of the protection systems that began between 1936 and 1940, was gradually continued, between 1956-1960, 1967-1970, 1981-1985 and 1989-1990 until 1991, when these shore protection and development works of the coast were stopped [8]. Studies show that the Romanian coast is in a serious state in terms of erosion extension (about $60-70 \%$ of the length of the shore).

In order to minimize the coastal erosion, to increase the value of the coastal area and to create new tourist beach areas, numerous scientific and technical documentation for the elaboration of the Master Plan for the protection and rehabilitation of the coastal area of the Black Sea have been elaborated.

The Master Plan establishes the strategic vision regarding the management of the entire Romanian coast and ensures a prioritized, sustainable, long-term approach in order to manage and combat the consequences of erosion and the implications related to the environment, marine ecosystems, economic and social values of the coastal area and whose general objectives are:

- to protect and improve the quality of the environment and of the living standards of local communities along the Romanian Black Sea coast and

- to increase safety in the south coast, severely threatened by the destructive effects of the coastal erosion process [6].

\section{PROJECTS TO REDUCE COASTAL EROSION}

The entire Romanian shoreline of the Black Sea is subject to erosion under the conditions of changing coastal dynamics. In the Romanian coastal area, 50-60 years ago, there was a balance between erosion and deposits, thus the shoreline not undergoing major long-term changes. This balance was disturbed as a result of the appearance of anthropogenic factors. Therefore, the following causes of the imbalance between erosion and deposition have been identified: 
- sediment deficit reaching the Black Sea - most of the sediments transported by the inland rivers and the Danube are retained by the anthropic works: dams and accumulation lakes;

- the change of the coastal dynamics due to the anthropic factors of the coastal area (port works) - jetties built in the Sulina area direct the deposit of the alluviums towards the sea. The route of the sea currents was also disturbed by the construction of the ports Midia Năvodari, Constanța and Mangalia.

Apart from the influence of the anthropic factors, a very important role in the evolution of the beaches on the Romanian coast has the action of the waves on the shore line.

Since 2011, with the help of the Dobrogea-Litoral Water Basin Administration and the European Union, projects have been developed for the implementation of the Master Plan, in order to control the coastal erosion.

The coastal protection approach consists of designing and implementing the measures that come from a series of "hard" and "soft" structural rehabilitation solutions, methods introduced by the coastal engineering and which offer solutions in the integrated management of the coastal zone.

The Master Plan "Protection and rehabilitation of the coastal area" identified the priority projects in (Figure 1):

- phase I, which took place between 2013-2015 and is finalized. The works carried out on the southern part of the Romanian Black Sea coast, in the five areas of Mamaia Sud, Tomis Nord, Tomis Centru, Tomis Sud and Eforie Nord were aimed at creating a coastal protection system against erosion;

- in phase II, works that are considered to improve the coastal protection in the following locations / areas: 2 Mai, Mangalia - Saturn, Balta Mangalia - Venus - Aurora, Jupiter - Neptun, Olimp, Costinești, Eforie, Agigea, Tomis, Mamaia, Stavilare.

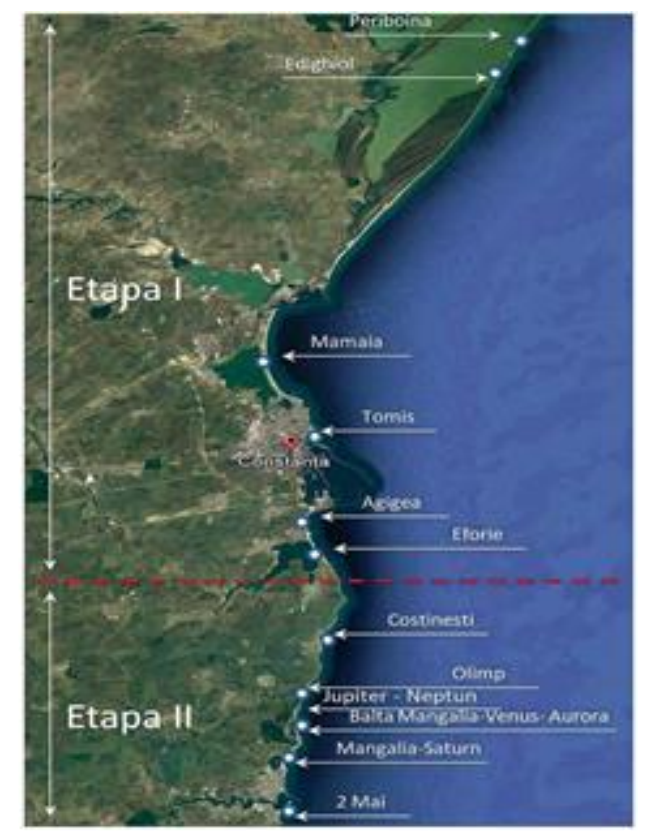

Fig. 1. Project "Reducing coastal erosion Phase II (2014 - 2020)" [9] 


\section{sciendo}

112 Ovidius University Annals Series: Civil Engineering, Year 21, 2019

Thus, one of the most important projects in terms of reducing coastal erosion was funded from the structural funds of the European Union through Halcrow Romania, respectively "Protection and rehabilitation of the southern part of the Romanian Black Sea coast in the area of Constanta and Eforie Nord" .

The project, funded by the European Commission through the Medium Sectoral Operational Program Priority Axis 5 Major Area of Intervention 2 - Reduction of Coastal Erosion, from the Cohesion Fund, has proposed the implementation of measures to protect the beach against the risk of accelerated erosion for the Mamaia Sud areas, Tomis Nord, Tomis Centru, Tomis Sud and Eforie Nord, over $7.3 \mathrm{~km}$ in length.

Within the project, works were carried out to repair the existing offshore breakwaters, the construction of new offshore breakwaters, the rehabilitation and extension of the protection breakwaters, the construction of protection dams in the sandy area and of buried dams (spurs), the demolition of existing structures and artificial sand works to widen the Romanian beach coast by over $60 \mathrm{~m}$ [7].

In 2018, the "Romanian Waters" National Administration through the Dobrogea Litoral Water Basin Administration signed the financing contract for the project "Reducing coastal erosion, Phase II (2014-2020)". The project is co-financed by the Large Infrastructure Operational Program (POIM) 2014 - 2020, Priority Axis 5 - Promotion of adaptation to climate change, prevention and risk management, Specific objective 5.1 Reduction of the effects and damages on the population caused by the natural phenomena associated with the main risks accentuated by the changes climate, mainly from floods and coastal erosion [10].

The coastal erosion reduction works will be carried out for the following sectors: Coastal area (between Stăvilar Periboina and Stăvilar Edighiol) and South area of the coastal zone, respectively Mamaia Centru and Mamaia Nord, up to the limit of UAT Năvodari, Agigea, Eforie Centru, Eforie Sud, Costinești Sud, Mangalia (Olimp, Neptun, Jupiter - Venus, Saturn, Mangalia), 2 Mai, Port Tomis, to Constanta Port, Balta Mangalia.

The purpose of the project is to prevent coastal erosion through specific actions to limit its negative effects on the Romanian coastal areas, beaches and through rehabilitation and protection activities, including artificial sand works of th existing beach areas, connected or parallel coastal structures with shoreline, dams to stabilize the cliffs, dredging, support walls, etc. Also, a series of measures are envisaged, such as: the use of satellite monitoring techniques to identify the areas affected by the erosion phenomenon, the use of satellite technology for constructing projections on the evolution of the erosion phenomenon and the use of satellite technology to evaluate the impact of the measures taken to limit the phenomenon of coastal erosion.

All of these will lead to the development of an environment suitable for increasing the conservation value of marine habitats in the project areas and for ensuring the conditions for preserving and supporting the future development of marine species with high conservative value.

\section{CONCLUSION}

The projects from non-reimbursable European funds to reduce erosion of the Romanian Black Sea coastal area have the following objectives:

- protection and rehabilitation of the Romanian coastal area and environmental factors, through engineering works to fight against the phenomenon of coastal erosion; 
- supporting the tendency to revive the marine ecosystem and to develop species lost at some point in the ecosystem;

- protecting marine biodiversity and the coastal area, as well as the sustainable development of the coastal area.

The works for the protection and rehabilitation of the Romanian Black Sea coastal area aim to protect and improve the quality of the environment and the standard of living, to increase the public safety, especially, where the defense structures are in an inadequate state and the coast is subjected, largely to the impact of erosion.

On the other hand, the non-implementation of the project "Reducing coastal erosion, Phase II (2014-2020)" will have as a consequence the continuation of the coastal erosion process, with negative effects on the biodiversity, as a result of the structural and functional deterioration of the existing hydrotechnical works, including the potential loss of some terrestrial and aquatic habitats.

Coastal erosion is a very dangerous phenomenon both for the environment and for the population, material goods, cultural heritage, and landscape, protected areas in the marine area and in the area bordering the Romanian coast.

\section{ACKNOWLEDGEMENTS}

This work has been supported by the European Commission through the European Maritime and Fisheries Fund, Cross-border Maritime Spatial Planning for Black Sea Bulgaria and Romania (MARSPLAN-BS II), EASME/EMFF/2018/1.2.1.5/01/SI2.806725MARSPLAN-BS II.

\section{REFERENCES}

[1] Marchand, M. (Ed.)., (2010), Concepts and Science for Coastal Erosion Management. Concise report for policy makers, Deltares, Delft, available at http://www.conscienceeu.net/documents/concise-report-final.pdf

[2] Mangor, K., Drønen, N.K., H. Kærgaard, K., E. Kristensen, S., (2017), Shoreline Management Guidelines, DHI, (4th edition) [Online], available at https://www.dhigroup.com/upload/campaigns/ShorelineManagementGuidelines_Feb2017.p df

[3] Petrişor, AI., Petrişor, LE., (2018), Transitional Dynamics Based Trend Analysis of Land Cover and Use Changes in Romania During 1990-2012, Present Environment and Sustainable Development, Vol. 12, no. 2, pp. 215-231

[4] Stan, M. I., (2014), The influence of coastal erosion on the development of southern Romanian Black Sea coastline, Journal of Industrial Design and Engineering Graphics, International Conference on History and Technology at the Black Sea region ISTM 2014, Romania, vol. 9/special issue, pp. 53-56

[5] Stan M.I., Vintilă D.F. and Țenea D.D., Engineering solutions for the management of the Black Sea coastal zone, International Multidisciplinary Scientific GeoConference SGEM 2014, 14th GeoConference on Water Resources. Forest, Marine and Ocean Ecosystems, Vol. 2, Bulgaria, 2014, pp. 577-584.

[6] Halcrow Romania (2012), Master Plan "Coastal zone protection and rehabilitation", available at: http://www.rowater.ro/dadobrogea

[7] Van Oord (2014), Presentation Report "Protection and rehabilitation of the southern part of the Romanian Black Sea coast in the South Tomis area and Eforie Nord", available at 


\section{sciendo}

114 Ovidius University Annals Series: Civil Engineering, Year 21, 2019

http://apmct.anpm.ro/documents/840114/2824541/Memoriu+prezentare+Tomis+Sud+++Ef orie+Nord+FINAL++03.03.pdf/9bf3cd8a-e825-4fb0-9e54-da3c12599c26

[8] Maritime Spatial Development Plan (MSP) - Black Sea, Component 1.1.1 Elaboration of detailed studies for a complete analysis of the Romanian and Bulgarian maritime areas [Online], available at http://www.marsplan.ro/ro/rezultate/studii-msp.html

[9] *** Project "Reducing coastal erosion Phase II (2014 - 2020)" [Online], available at http://apepaduri.gov.ro/wp-content/uploads/2018/06/Proiect-reducerea-eroziunii-costierefaza-II-2014-2020-01.jpg

[10] *** Dobrogea-Litoral Water Basin Administration, "Reducing Coastal Erosion Phase II (2014 - 2020)", available at http://www.rowater.ro/dadobrogea/

\section{Note:}

Mari-Isabella Stan - Ovidius University of Constanta, Bd. Mamaia nr. 124, 900356-Constanta, Romania (corresponding author to provide phone: +40-241-619040; fax: +40-241-618372; e-mail: stanisabella@yahoo.com).

Kamer-Ainur Aivaz - Ovidius University of Constanta, Bd. Mamaia nr. 124, 900356-Constanta, Romania (e-mail: aivaz_kamer@yahoo.com).

Ionela Ionițiu - Ovidius University of Constanta, Bd. Mamaia nr. 124, 900356-Constanta, Romania (email: ionelaionitiu@yahoo.com). 